кандидат педагогічних наук, доцент (Ізмаїльський державний гуманітарний університет) lessina tanya@ukr.net ORCID: $0000-\overline{0} 002-7923-2247$

\title{
КОНЦЕПТУАЛЬНІ ЗАСАДИ ПІДГОТОВКИ ВИХОВАТЕЛЯ ДО РОЗВИТКУ СОЦІАЛЬНИХ УМІНЬ І НАВИЧОК ДОШКІЛЬНИКІВ
}

У статті висвітлені деякі методологічні орієнтири розробки концепиії, яка спроможна розщирити принцииові уявлення про підготовку майбутніх вихователів до розвитку соціальних умінь $і$ навичок старших дошкільників. На основі аналізу наукового фонду, що нині склався, обтрунтовується системоутворювальні засади авторського підходу до визначення педагогічної стратегї підготовки вихователя до розвитку дошкільника як суб 'єкта соиіальної дії.

\begin{abstract}
Ключові слова: методологія, системний підхід, розвиток соиіальних умінь і навичок старших дошкільників, професійна підготовка майбутнього вихователя, системоутворювальні засади педагогічної стратегії підготовки педагога-дошкільника.
\end{abstract}

Постановка проблеми у загальному вигляді та їі зв'язок із важливими науковими і практичними завданнями. Пріоритетним напрямом реформування вітчизняної освіти є активізація соціальної активності вихованців, де ідеєю, що пожвавлює конструктивність особистісно-професійного впливу на дитину, визнано "зростання ії̈ небайдужою".

В цьому контексті актуалізується становлення особистості дитини як суб'єкта соціальної дії, здатність педагога успішно розв'язувати це завдання у професійній діяльності. Якщо ж ураховувати самостійність такого ланцюжка вітчизняної системи освіти, яким визнано дошкілля, то стає зрозумілою і значущість готовності майбутнього вихователя щодо вищеокресленого сегмента професійної діяльності, i роль сформованості у дитини дошкільного віку соціальних умінь та навичок - передумови ії успішного становлення як суб'єкта соціальної дії.

Натомість результати пілотного дослідження, проведеного нами з метою з'ясування здатності педагогівдошкільників (зокрема, деяких дошкільних закладів освіти Одещини) до розвитку соціальних умінь і навичок старших дошкільників, дозволяють зробити принаймні два узагальнення. Перше з них: переважна більшість респондентів відносить цей аспект соціального розвитку дитини старшого дошкільного віку до категорії "бажаного, але не обов'язкового". Друге узагальнення відтворює ситуацію, коли за самоцінними судженнями студентів, які набувають у вищій школі спеціальність "Дошкільна освіта" і $є$ випускниками бакалаврату, "практично готовими" себе вважають 19\% опитаних; "більш готовим, ніж неготовим" приблизно кожний третій з них; "більш неготовими, ніж готовими" - 29 \%, а "не готовими" визнали себе $18 \%$ респондентів (звісно, якщо йдеться про результат підготовки саме до вище окресленої сфери фахової діяльності).

Отож, можна припустити, що недосконалою є професійна підготовка майбутнього вихователя закладу освіти до розвитку соціальних умінь і навичок у старших дошкільників та невикористаними залишаються ресурси саме вищої школи - основного етапу професійного становлення фахівця.

Аналіз останніх досліджень і публікацій із зазначеної проблеми. Вивчення і узагальнення наукової літератури з проблематики професійної підготовки майбутнього педагога-вихователя (Л. Богуш, Т. Величко, Ю. Волинець, О. Листопад, В. Любива, Н. Хворостивська та ін.) засвідчують, що певні теоретико-методичні аспекти професійної підготовки майбутніх вихователів досліджувалися як на фундаментальному рівні, так і осмислювалися побіжно - з огляду на своєрідність предмета вивчення дослідника. Наприклад, С. Гаврилюк, досліджуючи означений процес за вектором здатності майбутнього фахівця до педагогічної творчості, встановила: у дошкільному віці дитини своєрідним "внутрішнім генератором" саморозвитку та самовдосконалення є іiі пошукова творча діяльність, а здатність педагога впливати на дитячу творчість інтенсивно розвивається, якщо активізується інтерес студентів до педагогічних інновацій [1]. Такий ракурс проведеного дослідження дозволяє, з одного боку, враховувати ресурси соціального розвитку саме дитини дошкільного віку, а з іншого - на етапі визначення технолого-методичного концепту дослідження процесу професійної підготовки педагога-дошкільника більш прискіпливо поставитися до вибору оптимальної технології становлення "мотивованого студента", тобто такого, який би позитивно-активно відносився до педагогічних інновацій. У зв'язку із зазначеним привертають увагу напрацювання тих науковців, які вивчають методику створення у вищій школі педагогічних умов, що сприяють формуванню майбутнього фахівця - суб'єкта професійної діяльності. Так, ураховуючи важливість набуття майбутнім спеціалістами соціономічної сфери у період університетської освіти досвіду суб'єктності, К. Віцукаєва окреслює сукупність таких педагогічних умов: наявність стійкої мотивації студента до вияву власної позиції у майбутній професійній діяльності; забезпечення інтегративних знань, умінь і навичок майбутнього фахівця 
щодо реалізації суб'єктності у професійній діяльності; встановлення міжпредметних зв'язків з-поміж дисциплін професійно-орієнтованої підготовки студентів [2: 43-44]. Зазначене складає певний практичний інтерес, насамперед, у такій площині: визначаючи теоретико-методологічний концепт дослідження процесу підготовки саме майбутнього педагога-вихователя як фахівця-соціономіста, доречно вбачати контекстність обраного дослідницького підходу.

Відмітимо, що нині вже склався певний науковий фонд, який віддзеркалює результати проведеного дослідниками аналізу своєрідності підготовки майбутнього вихователя у зарубіжжі. Так, дослідники, які вивчають становлення і розвиток фахівця з дошкільної освіти в умовах американських вишів (Н. Мельник, А. Чичук та ін.), зауважують на доцільності творчого запозичення ідеї гуманітарного (персоналістичного) підходу до підготовки студентів. При цьому дослідниками доведено, що у такий спосіб видається за можливе з-поміж компетентностей, яких набуває студент (зокрема, Державного університету Монтклеа), ще й успішно підготувати його до зміцнення здоров'я (у тому числі й соціального) та всебічного розвитку дошкільнят. У окресленій площині інтерес становить і дослідження сталої практики підготовки педагогівдошкільників у Польщі (М. Варшауер), у Турецькій Республіці (М. Дегирменджі) через успішне запровадження синхронної моделі компетентнісного й особистісного підходів. Отож, звернення до висновків педагогів-компаративістів дозволяє скоригувати наш дослідницький задум щодо вивчення проблемних питань професійної підготовки майбутнього вихователя до розвитку соціальних умінь і навичок старших дошкільників.

Мета статті - висвітлити деякі аспекти методологічного вектору стратегії підготовки студентів до конструктивного розвитку дитини старшого дошкільного віку як суб'єкта соціальної дії.

Виклад основного матеріалу дослідження. I накопичений досвід дошкільної освіти, і результати досліджень, присвячених удосконаленню професійної підготовки студентів, які у сучасному виші набувають спеціальність "Дошкільна освіта", актуалізують необхідність всебічного вивчення чинників, що обумовлюють позитивну соціальну інтеграцію вихованця. Особистісно-професійна готовність педагогадошкільника у зазначеному ракурсі складає один із вирішальних чинників. Відтак постає проблемним питання розробки відповідної конструктивної педагогічної концепції. Йдеться про визначеність у важливому параметрі започаткованого дослідження, бо концепція (від лат. "conception") трактується як той спосіб розуміння, як такий "провідний задум" або "конструктивний принцип" досліджуваного явища (процесу), який "задає" вектори змістового наповнення "моделей-концептів".

Відмітимо, що сутність концептуалізації висвітлена у науковій літературі. Ми приймаємо наукову позицію тих науковців (Р. Гурін), які вбачають у науковій концептуалізації віднаходження необхідних концептів та встановлення між ними зв'язків - віддзеркалення предметної галузі наукового знання. У такий спосіб (за М. Хеллманом) і розробляється модель-концепт, що слугує не лише відтворенням розумінняпояснення, а й визначальним інструментарієм щодо "допустимого спектру різних шляхів динаміки системи".

Отож, як відомо, саме системний підхід передбачає системний аналіз, зокрема процесу, який є предметом і нашої дослідницької уваги. Системність виступає важливою його характеристикою, бо йдеться про упорядковану множинність елементів, де, за М. Каганом, утворюються особливі якості цього процесу як цілісності, що "не зводяться" до властивостей елементів [3: 19].

Методологічна значущість системного підходу визначається ще й тим, що будь-яке педагогічне явище або процес представляється як система у тому сенсі, у якому вона трактується сучасними науковцями (П. Анохін, М. Каган, В. Садоський, Е. Юдін та ін.). Йдеться, зокрема, про визнання процесу підготовки майбутнього вихователя як такого, що має базовою характеристикою системність. Якщо ж виходити із поняття "педагогічна система" у тому значенні, що найпершим було надано Я. Мамонтовим, то слід враховувати ще й такі якісні характеристики системи, як-от: цілісність; наявність "закономірного сполучення" необхідних для будь-якої системи елементів, однак при цьому виключається випадкова підпорядкованість меті усіх чинників цієї системи та відношень між ними [4: 11].

До зазначеного додамо: предметом нашої дослідницької уваги є вивчення саме соціального об'єкта, а, відтак, доцільно врахувати вагу системного підходу через призму трактування довідковими джерелами соціальних термінів, тобто означений підхід розцінюється "і як теорія, і як метод пізнання".

Розробляючи системоутворювальні складові концепції дослідження, ми намагались урахувати істотні досягнення науковців у розробленні компетентнісного підходу (І. Зимня, О. Овчарук, О. Пометун, В. Сластьонін, Ю. Татур та ін.). Йдеться, насамперед, про доведення його спроможності "перенести" смисловий контекст діяльності особистості від функціонального до перетворювального. I науковці, i практики єдині у визнанні домінантою компетентнісного підходу - "знання в дії". Мають рацію і ті науковці (О. Вербицький, О. Ларіанова), які особливо відзначають потенціал такого підходу щодо різнопланових змін у професійній освіті, а також ті дослідники (насамперед, О. Огієнко), які стверджують: окреслений підхід дозволяє максимально врахувати запити суспільства та економіки до підготовки саме конкурентоздатного спеціаліста.

Водночас ми поділяємо думку і тих дослідників своєрідності компетентнісного підходу, які деталізують у ньому знаннєвий компонент. Так, аналізуючи результати проведеного Г. Сльніковою дослідження, 
вважаємо правомірним все ж розрізняти, по-перше, "знання-ознайомлення", які характеризуються формулюванням поняття у такий спосіб, як-от: "що називається...?"; по-друге, "репродуктивні знання", що проектуються на вимогу: "розкрийте поняття..."; по-третє, "конструктивні знання, уміння"; а вони віддзеркалюють зв'язки між певними поняттями або системою понять (типу: "чим вирізняється...?"); почетверте, "креативні знання, уміння", які пов’язані із переносом у нову ситуацію (типу: "змоделюйте...", "розробіть проект...", "надайте характеристику власного бачення..."). Отож, розуміючи компетентність особистості, зокрема, майбутнього вихователя дошкільного закладу освіти, як інтегроване особистіснопрофесійне утворення, стає очевидним, чому компетентність (як якість) не має професійних меж. До того ж, відомою в педагогіці вищої школи є позиція, за якою інтегративність убачається через такі близькі поняття, як "компетентність" і "професіоналізм". Наприклад, зауважимо у цьому зв'язку на двох протилежних точках зору: професіоналізм особистості інтегрується у компетентність (К. Віаніс-Трофименко, Г. Лісовенко); професійна компетентність особистості виступає як складник ії професіоналізму (А. Маркова, О. Ткаченко).

У зв'язку із зазначеним принагідно відмітимо думку Н. Гузій щодо професіоналізму як наукового критерію: за ознакою професії саме професіоналізм виступає "найбільш узагальненою, базовою характеристикою" [5: 120].

Вищезазначене та своєрідність предмета нашої дослідницької уваги, дозволяють зауважити ще на одному параметрі, який простежується в результаті теоретичного огляду напрацювань дослідників у ракурсі проблематики інтегративності. 3 цією метою звернемося до висновків М. Прокоф'євої, яка розробила інтегровану модель підготовки вихователя дошкільного закладу освіти і вчителя початкових класів. Отож, у такій площині дослідниця трактує педагогічну інтеграцію одночасно і як процес, і як результат руху, що характеризується взаємозв'язками і взаємопроникненнями тих явищ, які призводять до виникнення цілісності, системності нової інтегральної якості. Ми поділяємо таку позицію, оскільки вона, на наш погляд, найбільш переконливо пояснює взаємодію компетентнісного та інтегрованого підходів. А це має виняткове значення у зв’язку із намаганням визначитися у системоутворювальних складових концепції професійної підготовки майбутнього педагога-дошкільника до розвитку соціальних умінь i навичок старших дошкільників.

Вбачаємо доцільним констатувати, що ставлячи за мету розробити конструктивну концепцію дослідження, нами враховувалися ще й прийнамні такі зауваги. По-перше, принципову вагу набуття студентом статусності "діючого суб'єкта" вищеокресленого сегмента його професійної діяльності. Так, узагальнюючи погляди вчених (К. Абульханова-Славська, П. Гальперин, С. Дерябо, С. Ісаєв, С. Зимня, К. Мередіт, Дж. Стіл, Ч. Темпл, П. Штомка), маємо підстави обгрунтованість означеної позиції вбачати в тому, що: 1) майбутній вихователь стає діючим суб'єктом за умов активного впливу на реальну педагогічну ситуацію; 2) у структурі суб'єктивності розрізняють активність (у формах відповідальності, самостійності, суверенності, самодостатності) та здатності особистості до інтеграції; 3) особистість, набуваючи ознаки самовпорядкованості, самопричинності, саморозвитку, має наявною здатність "перетворювати" власну життєдіяльність, тобто планувати стратегію своїх дій, їх реалізувати, оцінюючи результативність діяльності в цілому. Отож, суб’єктивний "вимір" особистості майбутнього вихователя набуває позитивний вплив на саморегуляцію, стимулювання до діяльності, здатність (у певних межах) цілеспрямовано змінювати оточуючий світ і самого себе.

По-друге, визнання виключного значення, якого набуває всебічне осмислення специфіки того особистісного новоутворення, на розвиток якого й спрямована діяльність фахівця; йдеться про розвиток соціальних умінь і навичок саме старших дошкільників. Наприклад, С. Рубінштейн відзначає: "Не вміючи проникнути у внутрішній зміст дій і вчинків дитини, в мотиви іiї дій і внутрішнє відношення до завдань, які перед нею ставляться, вихователь-вчитель по суті працює навпомацки" [6: 188].

Висновки. Отже, враховуючи сучасні наукові уявлення про професійну підготовку вихователя-педагога та роль вищої школи (як педагогічної системи) щодо становлення успішного фахівця, а також "пояснювально-формувальну" потужність відповідних науково визнаних підходів у цьому плані, створюється можливість визначити конструктивну концепцію дослідження. Виходячи при цьому із базового значення, якого набуває в ній конструкт "розвиток соціальних умінь і навичок старших дошкільників", обгрунтованою є позиція, де йдеться одночасно і про важливий сегмент професійної діяльності сучасного педагога-дошкільника.

Перспективи подалыших наукових розвідок ми пов'язуємо із уточненням авторської позиції щодо змістового наповнення вище окресленого конструкта.

\section{СПИСОК ВИКОРИСТАНИХ ДЖЕРЕЛ ТА ЛІТЕРАТУРИ}

1. Гаврилюк С. М. Професійна підготовка майбутніх вихователів дошкільних навчальних закладів до педагогічної творчості: теорія і методика : [монографія] / С. М. Гаврилюк. - Умань : вид. "Сучінський М. М.", 2015. - 352 с.

2. Віцукаєва К. М. Методика організації педагогічних умов підготовки фахівця соціономічної сфери як суб'єкта професійної діяльності / К. М. Віцукаєва // Формування особистості фахівців соціономічної сфери: стратегія і тактика : [монографія]. - Одеса : Вид. Букаєв В. В., 2017. - С. 42-97.

3. Каган М. С. Системный подход и гуманитарное знание / М. С. Каган. - Л. : ЛГУ, 1991. - 354 с. 
4. Мамонтов Я. А. Хрестоматія сучасних педагогічних течій / Я. А. Мамонтов. - Харків : Держвидав України, 1926. $-635 \mathrm{c}$.

5. Педагогічна творчість, майстерність, професіоналізм у системі підготовки освітянських кадрів: здобутки, пошуки, перспективи : [монографія] / кер. авт. кол. Н. В. Гузій. - К. : Вид-во НПУ ім. Драгоманова, 2015. - 432 с.

6. Рубинштейн С. Л. Проблемы общей психологии / С. Л. Рубинштейн. - М. : Педагогика, 1976. - 423 c.

\section{REFERENCES (TRANSLATED AND TRANSLITERATED)}

1. Havryliuk S. M. Profesiina pidhotovka maybutnikh vykhovateliv doshkilnykh navchalnykh zakladiv do pedahohichnoyi tvorchosti : teoriia i metodyka [Professional Training of Future Educators of Pre-school Educational Institutions for Pedagogical Creativity : Theory and Methodology] : [monohrafiia]. - Uman' : vyd. "Suchinskiy M. M.", 2015. - $352 \mathrm{~s}$.

2. Vitsukaieva K. M. Metodyka orhanizatsii pedahohichnykh umov pidhotovky fakhivtsia sotsionomichnoyi sfery yak subiekta profesinoi diialnosti [Methodology of Organization of Pedagogical Conditions for the Specialist of the Socionomic Sphere as a Subject of Professional Activity]/ K. M. Vitsukaieva // Formuvannia osobystosti fakhivtsiv sotsionomichnoyi sfery : stratehiya i taktyka [Formation of the Personality of Experts in the Sphere of Sociology : Strategy and Tactics] : [monohrafiia]. - Odesa : Vyd. Bukayev V. V., 2017. - S. 42-97.

3. Kagan M. S. Sistemnii podkhod i gumanitarnoe znanie [System Approach and Humanitarian Knowledge] / M. S. Kagan. - L. : LHU, 1991. $-354 \mathrm{~s}$.

4. Mamontov Ya. A. Khrestomatiia suchasnykh pedahohichnykh techii [Textbook of Modern Pedagogical Trends ]/ Ya. A. Mamontov. - Kharkiv : Derzhvydav Ukrainy, 1926. - $635 \mathrm{~s}$.

5. Pedahohichna tvorchist, maysternist, profesionalizm u systemi pidhotovky osvityanskykh kadriv : zdobutky, poshuky, perspektyvy [Pedagogical Creativity, Skill, Professionalism in the System of Training of Educational Personnel: Achievements, Searches, Perspectives] : [monohrafiia] / ker. avt. kol. N. V. Huzii. - K. : Vyd-vo NPU im. Drahomanova, 2015. $-432 \mathrm{~s}$

6. Rubinshtein S. L. Problemy obshchei psihologii [Problems of General Psychology]/ S. L. Rubinshtein. - M. : Pedagogika, 1976. $-423 \mathrm{~s}$.

\section{Лесина Т. Н. Концептуальные основы подготовки воспитателя к развитию социальных учений и навыков дошкольников.}

В статье освещены некоторые методологические ориентиры, связанные с разработкой конщепции, позволяюшей расширить устоявшиеся научные представления о подготовке будущих воспитателей к развитию сочиильных умений и навыков старших дошкольников. На основе анализа сложившегося научного фонда обосновывается системообразующая основа авторского подхода к определению педагогической стратегии подготовки воспитателя к развитию старшего дошкольника как субъекта сочиального действия.

Ключевые слова: методология, системный подход, развитие социальных умений и навыков старших дошкольников, профессиональная подготовка будущего воспитателя, системообразующая основа педагогической стратегии подготовки педагога-дошкольника.

\section{Lesina T. M. Conceptual Foundations of Teacher Training for the Development of Social Skills and Skills of Preschoolers.}

The article considers some parameters of the systemic approach - the methodological basis for the development of the pedagogical strategy for training the future preschool teacher for the development of senior preschool children' social abilities and skills. Attention is focused on the interrelation, interdependence and interdetermination of the basic ideas of systemic nature with the dominants of synergetic, axiological, acmeological approaches with a view to comprehensively comprehending the specifics of the process of training the future preschool teacher for the development of the child as a subject of social action. In particular, in the context of the synergetic approach, we obtain the understanding of how, for example, "chaos" becomes the basis of the creative principle. According to the acmeological approach, we consider the position when the subject of the pedagogical activity, in this case, the teacher of a preschool educational institution, is guided by the possibility of achieving high results in the professional activity. Such a vector of resource reflection of the above mentioned approaches has allowed the author of the article to come to the conclusion that in developing the experimental strategy of training a preschool teacher who is capable of developing the child as a subject of social action, methodological guidelines for these strategies should be considered. It is also grounded that from the point of view of modern knowledge there is no universal approach to the study of pedagogical phenomena.

Key words: methodology, systemic approach, the development of social skills and habits of senior preschoolers, the professional training of the future preschool teacher, the system forming the basis of the pedagogical strategy for the preparation of a pre-school teacher. 